\title{
The gender equality potential of new anti-prostitution policy: a critical juncture for concrete reform
}

\author{
Emily St.Denny
}

\begin{abstract}
In April 2016, France adopted a new law enshrining a conception of prostitution as a form of violence against women that needed to be 'abolished' and setting up a complex policy framework to achieve this end. This framework comprises a criminal justice 'pillar' dedicated to prohibiting and punishing the purchase of sexual services, and a social service 'pillar' dedicated to providing financial and social sup- port to individuals involved in selling sexuniformly assumed to be women and systematically considered to be victims. The new policy was supposed to break from 70 years of symbolic politics characterised by ambiguous regulation, low political attention, and lax policy implementation. Drawing on documentary and interview data, and using the Gender Equality Policy in Practice framework to determine the policy's current and potential impact on women's rights and gender equality, this article argues that implementation of France's new anti-prostitution policy is currently at a critical juncture. Budget reductions, a lack of central state steering, and competing policy priorities are contributing to hollowing out the policy of its capacity to support individuals wishing to exit prostitution while possibly deteriorating the working conditions of those who cannot or do not wish to exit.
\end{abstract}

Keywords Prostitution/sex work · Abolitionism · France · Policy · Implementation · Gender equality

\section{Introduction}

In April 2016, France comprehensively reformed its policy on prostitution, passing a law that enshrined a conception of prostitution as a form of violence against women that needed to be 'abolished'. The new law established a complex policy framework comprising social policy measures to provide financial and social support to individuals involved in selling sexpredominantly assumed to be women and uniformly considered to be victims - and criminal justice measures aimed at preventing and punishing the exploitation of individuals in prostitution. The law's most high-profile measure was the criminalisation of the purchase of sexual services, making France the fifth country in the world to implement a demand-side ban on prostitution.

Those behind the policy hoped it would mark a watershed in the way France dealt with the issue of prostitution: 70 years of ambiguous regulation, low political attention, and lax policy implementation were to be replaced with a robust framework to rescue 'victims' and, in time, eradicate this form of 'gender violence'. Four years on, however, early evidence suggests that implementation issues pose a challenge in reaching these objectives. The policing and prosecution of clients is patchy and inconsistent between cities and regions. A combination of inadequate resourcing and authorities' unwillingness to grant migrants temporary residency means that very few 'victims' have been accepted into the exit programme. At the same time, sex workers' rights activists and community health groups argue that client 
criminalisation has had an adverse effect on individuals in prostitution by forcing them to accept riskier practices and hide from police and social workers.

Drawing on the Gender Equality Policy in Practice framework developed by Engeli and Mazur (2018) and presenting evidence from documentary analysis and interviews with policy actors, this article proposes the first systematic, if early, assessment of the implementation of France's new prostitution policy framework on a national scale. It argues that old habits, and especially a lack of government interest and commitment to funding and monitoring implementation, are re-emerging. This suggests that, at best, the policy is on track to being rendered merely symbolic, with little-to-no impact on gender norms and, at worst, it is having a detrimental effect on individuals in prostitution, especially the most vulnerable. The article is structured as follows: it first discusses the political framing of prostitution as a gendered morality policy issue, it secondly presents the historical evolution of contemporary French prostitution policy and discusses the conditions which brought about the 2016 prostitution policy reform, and it thirdly details the measures in the law and presents an analysis of their initial implementation, concluding with a discussion of the new law's potential impact on gender equality in France.

\section{Framing prostitution policy}

In France, as elsewhere, policy debates over prostitution and what ought to be done about it tend to be uncompromising and conflictual. The issue is framed as a moral one, via a process of morality politics that emphasises its association with fundamental social values, in particular those concerning sexual propriety and gender equality (Engeli and Varone 2011; Wagenaar and Altink 2012). To reflect the different and often antagonistic conceptions of prostitution, states have historically adopted one of the three approaches for dealing with it: prohibition; regulation; or abolitionism - a framework based on the abolition of regulation, the criminalisation of profiting from the prostitution of others, and the provision of social support to those involved in selling sex, who are inherently considered to be 'victims'. Since the late twentieth century, however, new models of national prostitution policy have emerged to address some of the perceived shortcomings associated with these original approaches. This includes the decriminalisation of voluntary sex work and, conversely, neoabolitionism, which seeks the 'abolition' of prostitution by means of client criminalisation (Abel and Fitzgerald 2010; Skilbrei and Holmström 2011).

These national prostitution policy models constitute more than abstract ideal types; they represent the lenses through which states' legitimate involvement with the issue is imagined, interpreted, implemented, and justified. Furthermore, they tend not to be translated into simple laws and programmes. Rather, the values and objectives they aspire to are enacted by means of complex governance frameworks. These frameworks align ideas, institutions, and interests in order to structure and integrate policy goals and action concerning prostitution. In other words, these approaches amount to policy regimes that present and embody different interpretations of what prostitution is, why it is problematic, whether/how the state should intervene (St.Denny 2017).

Moreover, prostitution policy is intrinsically linked to norms and beliefs concerning gender, sexuality, and women's bodily autonomy. The laws crafted, and the manner in which they are applied, directly affect the status and well-being of women, especially those involved in prostitution. Implementation of prostitution policy, however, is the result of a process of interpretation. Policymakers' initial intentions-the values and objectives they seek to communicate in the policy they have introduced-are never perfectly unambiguous. 
Consequently, implementation agents must make sense of policy before attempting to render them into practically feasible programmes. This context-specific process of interpretation, translation, construction, and transposition of meaning into action can, and in the case of prostitution policy often does, lead to unintended outcomes. The issue's complexity and its association with issues of gender and morality, that is to say beliefs concerning right and wrong or 'good' and 'bad' behaviour, entail a high degree of reactivity and interpretation by local actors, who apply national policy through the lens of their personal experience, understanding, and values (Wagenaar 2017: 47). There is, in essence, as many prostitution policies as there are actors responsible for implementation.

This article utilises the Gender Equality Policy in Practice (GEPP) analytical framework (Engeli and Mazur 2018) to assess the potential of France's new prostitution laws for influencing gender equality and the status, welfare, and rights of women. The framework invites us to consider the gender equality potential of policies beyond that initially intended by lawmakers at the policy formulation phase, and into their enactment and evaluation. A policy's influence on maintaining, advancing, or degrading gender equality is therefore decanted into three 'conceptual components': the nature of the policy's outputs and their congruence with gender equality goals; the empowerment (or not) of women's policy actors by and during the implementation process; and the ultimate influence of its out- puts on women's status and gender equality more generally. In the case of con- temporary French prostitution policy, this requires answering three questions:

1. Has the law been transposed into outputs that are amenable to improving the condition of women, especially women involved in prostitution?

2. Have the actors responsible for delivering and evaluating the law's measures been empowered in the process?

3. Has the law measurably improved the condition of women, especially those involved in prostitution?

The case study is informed by documentary analysis and interviews with département-level women's rights delegates responsible for implementing key aspects of prostitution policy. The documentary data comprise over 1000 media and policy documents from 2010 to 2019, including news articles, parliamentary debate transcripts, and official government publications, and is supplemented by historical and documentary analysis of over another 2000 such texts covering the period from 1946 to 2016 undertaken in the context of a doctoral dissertation (St.Denny 2016). Semi-structured interviews were undertaken between June and December 2018. Respondents were invited from across the thirty-three first départements in metropolitan France to enact key measures of the new law. Ultimately, eight respondents, representing a geographically and demographically diverse range of areas (Table 1), agreed to participate in audio-recorded interviews.

\begin{tabular}{|l|l|l|l|}
\hline & Rural/Urban & Population density & $\begin{array}{l}\text { On a } \\
\text { border/migratory } \\
\text { path }\end{array}$ \\
\hline Interview 1 & Mostly rural & Low & YES \\
\hline Interview 2 & Mostly urban & High & YES \\
\hline
\end{tabular}




\begin{tabular}{|l|l|l|l|}
\hline Interview 3 & Mostly rural & Low & NO \\
\hline Interview 4 & Very urban & High & NO \\
\hline Interview 5 & Mostly urban & High & NO \\
\hline Interview 6 & Mostly rural & Mid & NO \\
\hline Interview 7 & Very urban & High & NO \\
\hline Interview 8 & Mostly rural & Mid & NO \\
\hline
\end{tabular}

Table 1: Geographic and demographic diversity represented by interviewees.

Gender equality and prostitution policy in France until 2011: symbolic policies implement a piecemeal abolitionist regime

Until the end of the Second World War, France lurched between prohibiting and regulating prostitution, at which point it began to abolish its regulatory framework. The country's extensive and historically entrenched system of municipally licensed brothels was dismantled in 1946 (Adler 1999: 51; Corbin 1996: 347; Maugère 2009: 162; Solé 1993: 23). The compulsory medical and police registration of women in (or suspected of being in) prostitution continued until 1960, when France signed the 1949 United Nations 'New York' convention on the 'Suppression of the Traffic in Persons and of the Exploitation of the Prostitution of Others'. The 'New York' convention sets out the parameters of an 'abolitionist' stance on prostitution, by requiring all signatories to 'abolish' any vestiges of regulation, including obligatory medical or police registration. The abolitionist policy framework erected in France in the wake of signing the 'New York' convention was founded on two principles. Firstly, it considers prostitution to be a social blight, and regards all individuals in prostitution as 'victims'. Second, those who organise, facilitate, encourage, or exploit it are subsequently considered to be criminals. These principles were rapidly transposed into law, forming the two policy 'pillars' underpinning France's new abolitionist stance on prostitution (Allwood 2006: 51). Consequently, since 1960, the French state has essentially sought to deal with prostitution on two fronts: pimping, procuring, and brothel-keeping are criminalised; and 'victims' - who are uniformly assumed to be women-are to be offered support to exit prostitution and become 'rehabilitated' members of society. To do so, new laws were created to punish the exploitation of prostitution and establish social and medical ser- vices tasked with providing support and rehabilitation to 'victims'.

From its inception, the story of France's abolitionist policy regime is one of the partial and inconsistent implementations. The police often used laws criminalising public indecency and soliciting to arrest and harass women in prostitution rather than punishing those who exploited them (Mathieu 2001; Mazur 2004). This tendency was exacerbated with the visible increase in street-based prostitution from the 1990s onwards, at a time when public order was particularly securitised (Allwood 2003, 2006; Des- champs 2005; Guienne 2006; Mathieu 2011; Vernier 2005). At the same time, very few local authorities ever dedicated the requisite time and resources to assisting individuals in prostitution, with abolitionist non-governmental organisations (NGOs), such as the Mouvement du Nid, stepping in to fill the gap.

For these reasons, France's post-war abolitionist regime, and in particular its social 'pillar', is best identified as a symbolic policy. Symbolic policies are those created to give a sense that a problem is being addressed, but without resources or energy being dedicated for actual implementation (Mazur 1995: 2). Policies with strong moral components are particularly 
prone to being symbolic (Wagenaar et al. 2017: 45). With such policies, the announcement of the law, with an emphasis on its normative value, matters more to policymakers than its sustained implementation over time (Mazur 1995: 3). Consequently, from the mid-1980s, in the midst of this implementation vacuum, groups began emerging which did not recognise prostitution inherently as a 'social ill'. These groups comprised mainly sex workers' rights activists, some of whom were or had been involved in prostitution, and community health groups dedicated to providing medical support to individuals in prostitution. These actors called for the decriminalisation of prostitution and an end to police harassment. While they were unsuccessful in their attempt to erode the existing dominant abolitionist orthodoxy, they nevertheless contributed to elevating the issue of prostitution policy reform onto the political agenda (Mathieu 2000, 2004).

\section{Getting criminalisation on the parliamentary agenda in 2011}

A window of opportunity for reform concretely emerged in the mid-2000s as a result of French feminist policymakers being sensitised to the issue of prostitution first during clashes with sex workers' rights activists wishing to introduce a distinction between putatively 'forced' and 'voluntary' prostitution in international debates (Allwood 2004, 2006; Deschamps 2007; Mathieu 2004), and second in response to the introduction of punitive antiprostitution laws as part of the 2003 Domestic Security law (see Allwood 2003, 2006; Danet 2006; Mathieu 2011, 2012; Maugère 2009; Mayer 2011). The consequence was a strong reaffirmation of the state's commitment to abolitionism in French policy discourse and the gradual institutionalisation of new feminist interpretations of prostitution as a form of violence against women (VAW) (Guiraud 2009). This redefinition of the policy 'problem' allowed feminist policymakers and their abolitionist coalition partners to demand reform and promote alternative policy solutions. In particular, calls to hold clients responsible for the role they played in perpetuating prostitution gained increasing political traction. Inspired by the Swedish law to this effect, client criminalisation was presented as a policy 'panacea' (Mathieu 2013a: 241, 2013b: 17): a single and overarching solution to the complex problem of prostitution. The criminalisation of the purchase of sexual services (CPSS) would enable the de facto prohibition of prostitution without punishing the 'victims' involved. Moreover, proponents argued, punishing clients could help address the seemingly antagonistic demands of different constituencies: it would eradicate prostitution, and therefore visible street-based soliciting in residential neighbour- hoods, while at the same time allowing 'victims' to be identified and helped by the state (Mathieu 2013b: 19).

Ultimately, a window of opportunity for advocates of CPSS to initiate a legislative debate over the future of French prostitution policy arose in 2010. That year marked the official recognition of prostitution as a form of violence against women and a national policy priority ('grande cause nationale') by the French state, as part of its third national anti-VAW programme (Ministère des Solidarités et de la Cohésion Sociale 2010), as well as the launch of a vast campaign for client criminalisation by a vast abolitionist coalition (Mouvement du Nid 2010: 9-10). The campaign brought together over 200 organisations and prominent public figures including: abolitionist NGOs such as the Mouvement $d u$ Nid, the Coalition Against Trafficking in Women, the French committee of the European Women's Lobby, and the Fondation Scelles; feminist activists, including members of SOS Sexisme and Regards de Femmes; trade unions; and a wide range of feminist politicians who supported CPSS. The aim of the campaign was to transform what policymakers and the public understood 'abolitionism' to mean. Specifically, they wanted to replace the historical interpretation of 
'abolitionism' as the abolition of state regulated prostitution with a new meaning that denoted the political will to abolish prostitution itself (Lemettre 2010; Mouvement du Nid 2010: 1).

In this context, a number of parliamentarians with strong ties to this abolitionist campaign announced their intention to create a cross-party committee to review the country's prostitution policy framework. From the outset, the committee announced its interest in studying the possibility of France adopting a demand-side ban on prostitution. The final report, published in April 2011, emphasised the need for France to renew its commitment to achieving abolition- ism's "ultimate goal" of a world without prostitution (Geoffroy 2011: 97). The authors argued that France's existing abolitionist policy framework, while laud- able in intention, often failed to provide sufficient support to 'victims' (ibid.: 16). The committee set out thirty recommendations to improve France's prostitution policy, including: training police officers to better identify and support 'victims'; allowing victims a rebate on unpaid taxes; guaranteeing residency rights to foreign victims of trafficking; and holding internet providers responsible for hosting sites that promote exploitation. The report's flagship recommendation, however, was that France introduce a law criminalising clients of prostitution.

\section{The adoption of the 2016 law: a neo-abolitionist regime is born}

While delayed by the 2012 presidential elections and its contentious nature, a bill inspired by the committee's recommendations and prepared by the National Assembly's Women's Rights Delegation was tabled in October 2013. The proposal received very mixed reactions. Some politicians on the Left, along with community health groups and sex workers' rights activists, voiced strong opposition against client criminalisation as posing a risk to individuals involved in prostitution by forcing them to work out of sight and reach of social workers and the police (e.g. Brigaud 2013; Ben- bassa in Pacione 2014; Cavard in Le Nouvel Observateur 2013a; Jeunes Radicaux de Gauche 2013; STRASS in Guérin 2013). Conversely, many politicians on the right argued that the bill's proposed decriminalisation of passive soliciting, a key and controversial element of the 2003 Domestic Security Bill's anti-prostitution measures, would increase street-based prostitution in their constituencies and encourage human trafficking networks (e.g. Jacob in Le Nouvel Observateur 2013b; Pécresse in RTL 2013).

After fraught and protracted parliamentary debates, the bill nevertheless was passed on 6 April 2016 and was introduced into the statute books 1 week later, on April 13, to mark the symbolic 70th anniversary of the law abolishing brothels. Much like the policy framework it succeeded, the new law rests on two policy 'pillars': a social policy pillar comprising measures to support 'victims' to exit prostitution, and a criminal jus- tice pillar intended to criminalise the exploitation and, now also the purchase, of sexual services. The new law transformed France's prostitution policy framework from a traditional abolitionist regime based on abolishing regulation to a neo-abolitionist one intent on abolishing prostitution itself.

\section{The policy instruments of the 2016 Loi Visant à Renforcer la Lutte Contre le Système Prostitutionnel}

The law's flagship measure to criminalise clients of prostitution was undoubtedly the most salient and hotly debated in the media. In reality, however, the law, which comprises 23 articles spanning 5 thematic chapters, represents a much vaster and more comprehensive overhaul of France's abolitionist policy regime. The law broadly contains two types of measures, which form its two policy 'pillars': 
- Administrative and social measures aimed at supporting 'victims' of prostitution and preventing entry into prostitution;

- Criminal justice offences to tackle and punish exploitation, human trafficking, and the purchase of sexual services.

The law's social pillar is made up primarily of 'incentive instruments', that is to say outputs intended to encourage certain behaviours without regulatory constraint (Engeli and Mazur 2018: 115). Specifically, it opens up new social entitlements for 'victims' seeking to exit prostitution, including: individualised assistance; the provision of sheltered accommodation; support to exit prostitution; support to re-train and secure employment; access to certain welfare benefits, such as a $€ 330$ per month stipend; and, for migrants, support to obtain temporary residency ( 6 month and renewable). Individuals can access these rights by applying to be part of an 'exit programme' (parcours de sortie). Responsibility for delivering this programme rests at the département level, with the Préfets, who are tasked with creating and chairing commissions bringing together public sector partners, including the police and social workers, to review and approve applications. However, operational responsibility for organising the commissions and overseeing the delivery of the exit programme is handed down to the département's women's rights delegate (déléguée départementale aux droits des femmes) - a position usually held by a single person, often within a broader department dedicated to social policy, and whose role it is to co-ordinate all gen- der equality policy across the whole département. In practical terms, these women's rights delegates organise meetings of the commission; co-ordinate partner- ship working to support 'victims' in accessing the rights and services they are entitled to; and subcontract and support at least one specialised not-for-profit organisation to accompany 'victims' through their exit journey.

By contrast, the law's criminal justice pillar is primarily comprised of 'authority instruments' (Engeli and Mazur 2018: 115): a series of bans and regulations prescribing behaviour. These measures are intended to deter and further punish the exploitation of prostitution, including by clients, who are recast as perpetrators of violence against women. It introduces harsher penalties for violence against individuals involved in prostitution as well as measures to protect victims of human trafficking when they choose to press charges against their abusers. However, the law's most high-profile measure, and its most contentious, namely the creation of a new offence for the purchase of sexual services, stands out as both an authority and a symbolic policy instrument. As an authority instrument, this measure introduces a fine of up to $€ 3750$ ( $€ 1500$ for a first offence) for clients of prostitution, along with the possibility of a custodial sentence for repeat offenders and the requirement in some cases to attend 'reeducation' sessions led by abolitionist organisations to learn about how prostitution constitutes a form of violence against women. This measure, however, was also intended to be symbolic (Engeli and Mazur 2018: 116), in the sense that it communicates strong normative beliefs concerning the unacceptability of prostitution and the non- commercial nature of women's bodies.

Learning and capacity instruments, intended to support or enhance actors' knowledge and coordination, with a view to embedding policy learning and improvement, did not feature prominently in the law though a requirement for the Government to publish an implementation evaluation within the first 2 years of the law's enactment was included. Together, these policy instruments were intended to embody and deliver the law's 
fundamental neo-abolitionist values. The 'exit programme' is the translation into policy action of the belief that individuals involved in prostitution are inherently 'victims' and require support from the state and society. The criminalisation of clients alongside the more robust penalisation of exploitation transposes the conviction that women's bodies are not objects that can be bought. The law's implementation is therefore likely to be of great significance for the condition of individuals in prostitution, as well as for the advancement of a particular conception of women's rights and gender equality.

\section{Implementing the social pillar in practice: the exit programme}

Despite a requirement to publish an evaluation of the new law's implementation by the spring of 2018 , no such study has yet been produced at the time of writing,1 though a statecommissioned case study of the law's application in four major cities was been released in 2019 (Guillement and Pohu 2019). As a result, official implementation data remain fragmentary and impressionistic. Nevertheless, early reports from actors involved in policy delivery, including the 2019 local evaluation, as well as the findings from the 2018 Senate Women's Rights committee inquiry into the law (Délégation aux Droits des Femmes du Sénat (DDFS) 2018a, b), suggest extreme differences between départements.

Nation-wide, implementation was initially delayed as a result of the late publication of ministerial guidelines on how to set up commissions (including a list of actors with statutory membership) and run the exit programme (including a list of eligibility criteria for organisations bidding to deliver the programme) (Ministère de la Famille, de l'Enfance et des Droits des Femmes 2016; Ministère des Affaires Sociales et de la Santé 2017). The first commissions dedicated to setting up the exit programme therefore only convened in early 2017, and the first candidates for the exit programme were proposed at the end of that year (Caradec and de Rugy in DDFS, 2018a, n.p). Today, there is evidence of commissions having been convened in seventy-one of the ninety-six départements in metropolitan France, with a further seven having taken steps to accredit a not-for-profit partner organisation for future delivery of the exit programme (Fig. 1).

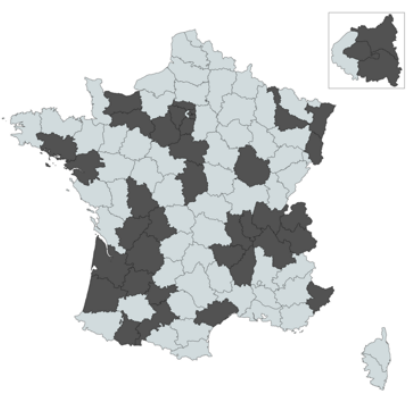

January 2018

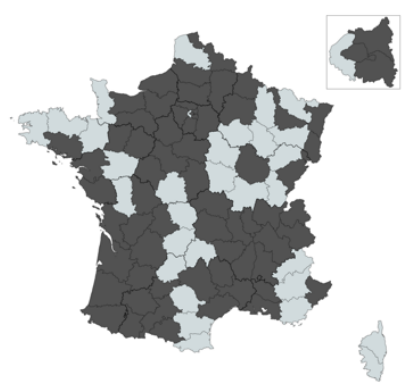

January 2019

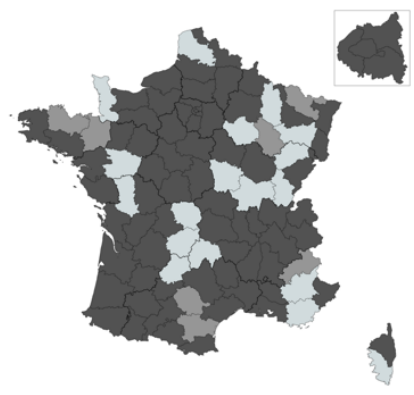

January 2020

Commissions established Associations agreed

Figure 1. Commissions established 2017-2020

Interview data suggest a link between the salience of the issue of prostitution among département policy actors and the ease with which a commission can be established and run. 
In particular, the pre-existence of networks aimed at tackling prostitution and supporting 'victims' appears to facilitate this process (Interviews 2 and 4). Conversely, where prostitution is a new or low salience policy topic, and in particular in more rural départements with little historical experience of visible and street-based prostitution, establishing a commission and developing a basis for partnership working have been challenging. One delegate recalls:

I started bringing up the topic of prostitution as soon as I took up my post, in 2013 [...]. Immediately there was resistance. I was told: "Are you crazy? There is no prostitution [here]! It doesn't exist". (Interview 3).

To make sure they fulfil their statutory obligations, some départements operating under the perception that there is no prostitution in their area have established commissions by prefectoral degree which, in reality, have never met and are wholly dormant (Interview 6). These 'paper' commissions skew the impression of how extensively the law is being applied across the country: most of the départements are now endowed with a commission, but it remains unclear whether they are all actively working towards preventing prostitution and supporting 'victims'.

In areas where the issue of prostitution is perceived as unimportant, especially among local public service partners such as the police, delegates may nevertheless try to use the law as a lever to raise awareness, even in the absence of 'victims' to put forward for the exit programme (Interviews 1, 3,6). Establishing and maintaining interest among such partners is challenging. One delegate evokes her experience:

We started out in 2017 with around twenty people. It's not a big number but it's pretty good for a département this size. Now only about ten people show up to commission meetings. Last time we were supposed to meet, fifteen people begged off, I was very disappointed (Interview 3 )

Moreover, setting up a commission, organising meetings, and processing exit programme applications depend heavily on support from the Préfet (Caradec and Slimani, in DDFS 2018a, n.p.; Dupont 2018: 21; Interviews 3, 4, 5, 8). The French Government had initially pledged to allow one thousand applicants per year into the exit programme. It has since reduced that number to six hundred and decreased funding accordingly (Caradec in DDFS, 2018a: n.p.). The number of successful applications remains very low, even in the context of shrinking Government targets: there were twenty-nine people involved in the programme by the end of 2017, sixty-four by April 2018, and only one hundred and eighty-three by April 2019 (Dupont, 2018: 19; Moran, 2019). Préfets refusing to validate applications remains the primary reason behind low participation (DDFS 2018a, 2018b; Moran, 2019). In particular, Préfects' have demonstrated a strong reticence to granting temporary residency permits to the many migrants applying to the programme (Interviews 1-8). Lack of adequate resourcing, and especially a dearth of specialised sheltered accommodation (Interviews 4-6, 8), has also put pressure on women's rights delegates to limit the number of applications they put forward for consideration (DDFS, 2018a).

While low overall, the number of applications approved also varies significantly between départements (DDFS, 2018a, 2018b; Moran, 2019; Interviews 1-8). In some départements, such as the Hérault and Drôme, almost all applications put to commissions have been successful (Dupont 2018: 22; Moran, 2019). In others, such as the Alpes-Maritimes, success 
rates are closer to 35\% (Ibid.). This is blamed on Préfects' wildly differing interpretation of eligibility (DDFS, 2018a; Interviews 2, 3, 7), which is facilitated by the absence of clear and unambiguous guidance:

There are serious questions that need to be clarified and that are currently simply a matter of interpretation at the département level: what does an 'exit programme' entail? If a person has already 'exited' prostitution but requires help to acquire residency papers, do they qualify for assistance? Does a person need to stay out of prostitution for good? At what point in the application process do they need to demonstrate they've exited? Etc... [...] I don't think the lawmakers really asked themselves these questions, that concern practical application and which only emerge when you try to imple- ment measures. (Interview 3 )

Another delegate remembers having to manage and repair relationships with third sector partners after exit programme applications were rejected by the Préfet:

We were encouraged to put forward applications. I [...], and the organisation I work with [...] spent a lot of time and energy putting everything together. [...] In the end, the applications were refused on the grounds that the women should apply for asylum in Italy, where they arrived in Europe. The fallout from the organisation I work with was significant - they felt deeply betrayed: they had gained these women's trust, encouraged them to apply, laboriously helped them get hold of many documents, and in the end they had to tell them their claim was rejected. [The organisation] currently refuses to work with us towards any new applications... and I don't blame them. (Interview 2)

In other cases, building and managing relationships with partners is difficult because of the absence of specialised organisations (Interviews $3,6,8$ ). To be eligible for the contract, an organisation must demonstrate a historical link with the locale (usually a presence of more than 3 years in the area) and a specific under-standing of the issues facing individuals involved in prostitution. Because they embody precisely these requirements, historical abolitionist organisations such as the Mouvement and Amicale du Nid have been very successful in their bids for partnership (see, for example, Amicale du Nid 2019: n.p.). Nevertheless, these organisations are not present in all départements (Caradec in DDFS, 2018a). As a result, a number of delegates have therefore had to stretch their limited time and budgets to either support specialised organisations in setting up a local branch in their area, or help generalist women's rights organisations gain specialist under- standing of the issue of prostitution. In a context where the state funding to civic organisations is being cut, the latter often have a strong incentive to compete for the public contract, which comes with its own funding package. This can, however, lead to mission drift and unintended consequences:

We didn't have any specialist organisations in my département so I worked with the local branch of [a womens' rights association] [...] so they could gain the necessary specialist knowledge and put in a bid for the accreditation, which they obtained. The problems started when they began working with women involved in prostitution: it turns out that, while the management had been active in putting together the bid, they hadn't consulted the front line staff who did not take to this 
new aspect of their job - they were very afraid of going to visit the women, afraid of being attacked by pimps [...]. It's made it very difficult to deliver any support services. (Interview 8)

Moreover, regional budgets for delivering the exit programme are unevenly distributed among the region's départements, with large urban hubs often getting the lion's share because of the perception that prostitution is more prevalent there (Interviews 1, 3, 4, 5, 6). For instance, a delegate from a densely populated and mostly urban département reports receiving $40 \%$ of the region's budget, with the remaining $60 \%$ shared across eleven other départements (Interview 5). Overall, both département-level delegates and national-level state feminists, such as those in the Senate Women's Rights committee (DDFS, 2018b), perceive a disconnect between the rhetorical commitment the Government has made to implementing the law and the lack of financial and human resources it has dedicated to its actual delivery. In effect, the prostitution policy 'portfolio' has been delegated to a handful of actors wielding small budgets, with limited time, and constrained by their lack of authority:

"When you're the only person, at the level of the département, and you're trying to be the 'hub', the 'brain', the 'spokesperson', the person who links every element in the network, it can become very heavy. You quickly feel solitary." (Interview 3)

"It's a huge amount of work, because we're effectively alone in the département. We do it all ourselves: organisation, logistics, report-writing, budget requests. Meanwhile, we're also responsible for delivering all other aspects of gender equality policy, including domestic violence prevention. It can be a very heavy load to carry" (Interview 5).

Nevertheless, despite recognising significant challenges to implementation, these actors unanimously claim the programme has been beneficial to those few who have received it, often sharing emotional anecdotes of individuals having been able to exit prostitution, retrain professionally, find work, and 'regain their dignity' (e.g. de Rugy in DDFS, 2018a; Mouvement du Nid 2017: 9).

\section{Implementing the criminal justice pillar in practice: client criminalisation}

The implementation of the new law to criminalise the purchase of sexual ser- vices has garnered a great deal of media attention since its introduction. To date, no official data have been published concerning the number of individuals either having been arrested and fined, or having been made to attend a re-education session. Estimates, however, remain relatively low: approximately 4000 convictions by October 2019 (Freynet 2019; see also Fig. 2). To place this number in context, an estimated $12-18 \%$ of men in France are thought to have purchased sexual ser- vices at least once (Barret 2013). 


\section{CPSS Conviction 2016-2020}

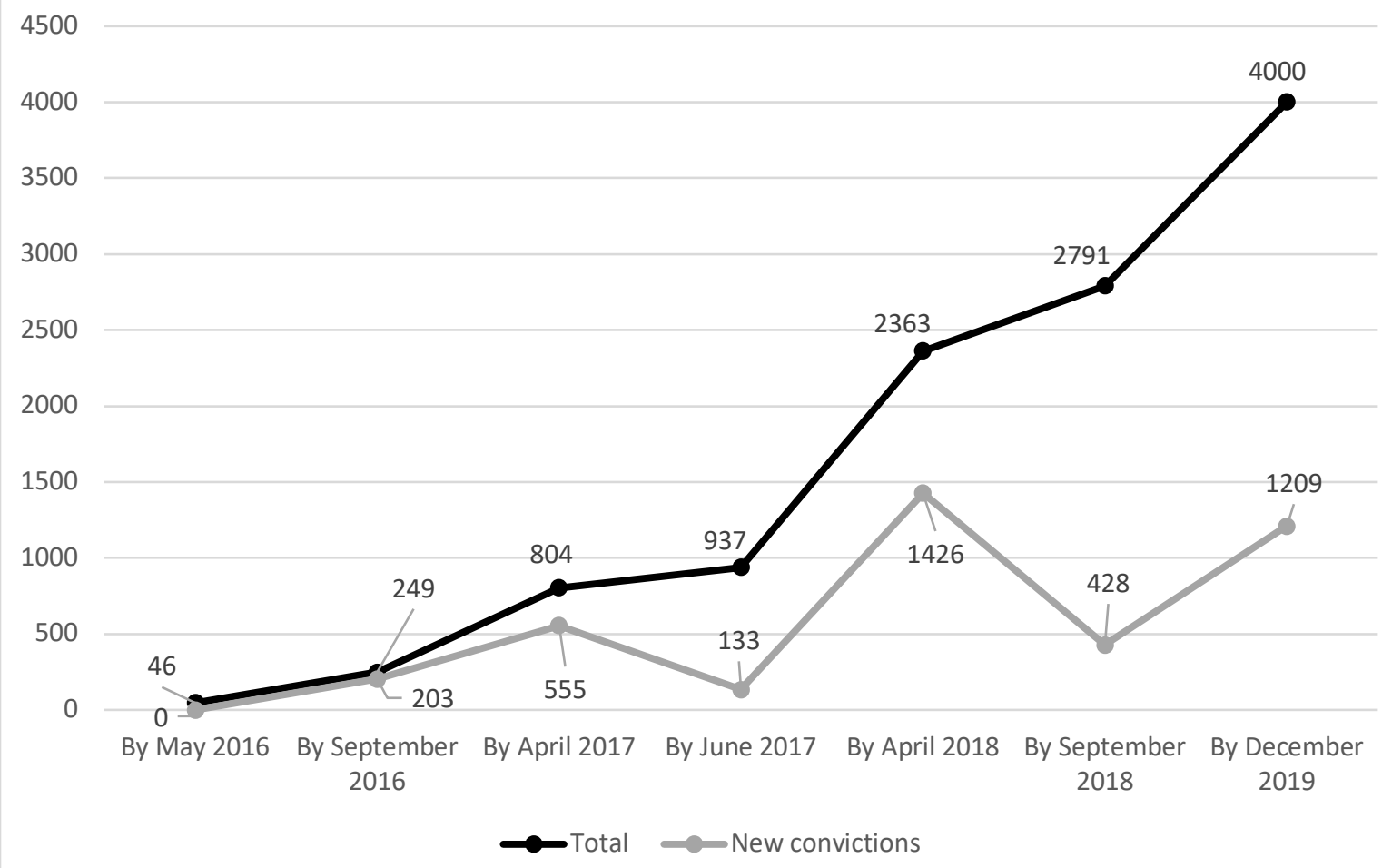

Figure 2 (Villeboeuf and L.C., 2016; Massonnet, 2016; Milhat, 2017; Vantighem, 2017; Colcombet, 2018; Goldmann, 2018; Freynet, 2019)

This low number is primarily explained by divergent practices by police forces, with a few applying the law systematically but most preferring to caution rather than charge first offenders. To date, over half of all convictions (2263) have taken place in Paris alone (L'Union 2019). By contrast, between 2016 and 2018, there have only been 49 recorded convictions in Toulouse (ActuToulouse 2018). Moreover, even when offenders are charged, their convictions tend to bear light penalties, with fines in the range of $€ 300-€ 550$ (Charkaoui 2018; Bize 2019). Finally, very few offenders are referred to 're-education' sessions. This is because of the lack of accredited programmes: by January 2018, only three départements were in a position to deliver this service (Le Parisien 2018). The leniency against clients is seen as particularly problematic in the light of evidence that some local councils, such as Toulouse and Lyon, still criminalise passive soliciting despite the offence having been repealed by the 2016 law (Maréchaux and Burlet 2018; Arsac in La Dépêche 2018; Le Bail et al. 2018).

Unlike the exit programme, which policymakers and civic actors broadly tend to agree benefits those involved, the impact of client criminalisation on individuals in prostitution is much more contested. Initial studies, as well as reports from specialised community health organisations, suggest a negative impact on many individuals involved in prostitution, as a result of losing clients (Le Bail et al. 2018; Acceptess-T et al. 2019). These outcomes include: a detrimental loss of earnings; the need to accept unsafe sexual practices in order to attract and retain clients; more frequent negative interactions with the police; increased stigma; and increased experience of violence (Le Bail et al. 2018). As a result, many com- munity health and sex workers' rights organisations have called for a repeal of the law. Recently, a coalition of such actors lost their case to have the law repealed on constitutional grounds, having 
claimed it infringed the rights to a private life and to free enterprise (Médecins du Monde et al. 2019; Seronet 2019).

Proponents of the law, and especially state feminists, however, remain strongly in favour of client criminalisation, claiming that it has helped 'change hearts and minds' and educate male clients, and society more broadly, about the unacceptability of prostitution (e.g. Rossignol in DDFS, 2018b). When confronted with the argument that this measure is harming precisely those individuals they consider 'victims', these advocates respond that prostitution itself is the violence they suffer from, not the law penalising clients (e.g. Goldschmidt in Colcombet 2018).

On the ground, however, women's policy actors, such as départemental Women's Rights Delegates, tend to disaggregate the effects of client criminalisation from that of the law's social support measures. For example, one argues that:

[T] he way client criminalisation is applied really isn't perfect and most likely has negative consequences for certain populations, but, [...] the efforts we're making to create département-level policies and develop partnership working to deliver support programmes improves outcomes for certain individuals (Interview 3 )

Co-ordinating the law's social and criminal justice measures in order to improve outcomes for 'victims' is part of their work. Yet bridging the two aspects of the policy, especially in terms of developing a common understanding of priorities and practices between the police and other actors, remains one of the biggest challenges these delegates face: "Of all the partners, the police are the ones who are hardest to work with. They worry that the exit programmes, through which people can access temporary residency permits, will be used by traffickers to get more people across: smuggle the people and tell them that if they prostitute themselves, they can then ask for support to 'exit' and maybe get residency rights" (Interview 7). As a result, many local police forces prefer to concern themselves with dismantling trafficking rings than arresting clients. As a result, the new law banning the purchase of sexual services has not had a clear or notable effect on reducing the prevalence of prostitution. While visible street-based prostitution has declined in certain areas, such as near the southern city of Narbonne, is has remained stable in other big cities such as Bordeaux, Strasbourg and Paris (Guillemet and Pohu 2019: 32, 80, 121, 151). Moreover, authorities caution that, while streetbased prostitution may be gradually decreasing, a growing number of individuals appear to be moving indoors and using the Internet to solicit clients (e.g. Ibid.: 39).

Nonetheless, initial data suggest that the law may be starting to have the desired effect of transforming broader social norms. French society has traditionally been in favour of a return to a regulationist system of licensed brothels. Public backing for brothels has historically been based on a widely shared belief that prostitution is inevitable and that regulation helps prevent the spread of sexually transmitted dis- ease (Mathieu 2000). Support such for regulationist ideas peaked at $75 \%$ in 2013 when the prostitution policy reform bill was tabled, up from 55\% in 1970 (IFOP 2013). Three years after the introduction of the new, however, a recent survey found that up to $78 \%$ of people now support client criminalisation and $73 \%$ now perceive prostitution as a form of VAW (Ipsos, in Le Parisien 2019a).

\section{Assessing empowerment and gender transformation in the context of the $\mathbf{2 0 1 6}$ law}

The implications of the 2016 law for gender equality are complex and potentially profound. Currently, however, all the evidence suggests that the policy is facing a critical juncture, both 
in terms of its continued capacity to empower the feminist actors involved shaping and delivering its implementation, and in terms of its capacity to transform gender norms and relations. Put simply, without adequate resourcing and renewed political commitment from the French Government, the reform will be permanently 'hollowed out' and rendered little more than symbolic, much like the post-war regime it was meant to replace.

Firstly, there is a clear contrast in the pre- and post-legislative presence and role of feminist policy actors in this policy domain. Prior to the law's adoption, these actors led efforts to set the policy agenda and open a window of opportunity for reform. In particular, abolitionist state feminists were instrumental in reframing prostitution as a form of violence against women and securing a reform that included client criminalisation, in the face of considerable public and political contestation. In the immediate post-legislative phase, département-level feminist actors, in the form of women's rights delegates, were also substantively empowered to shape and deliver key measures of the new law. This includes operational responsibility for setting up and running the partnerships through which individuals wishing to exit prostitution can access practical and specialised support.

Nevertheless, insufficient resources, reluctance from police and immigration authorities to work in partnership, and the overall decline of the salience of prostitution on the national policy agenda have contributed to eroding women's policy actors' empowerment in the implementation process. On the one hand, state feminists are struggling to replace the issue of prostitution on the national policy agenda. In November 2017, the French Government declared gender equality a national priority ('grande cause du quiquennat'), but has remained largely silent about the issue of prostitution, despite it having officially been recognised as a form of VAW. Feminist policy and abolitionist NGO actors' calls for renewed political commitment, steering from the central government (e.g. Olivier in Colcombet 2018; Slimani, in DDFS 2018a), and a budget increase have been largely ignored.

Secondly, and as a consequence of its piecemeal implementation, the law's trans- formative ambitions have yet to be realised. The result is a high degree of policy continuity rather than divergence. The reform was supposed to herald a step change in the way the state dealt with prostitution. Decades of government inaction, poor implementation, and lack of support to 'victims' were to be replaced by a robust neo-abolitionist framework intended to provide not only concrete measure to eradicate the violence and hardships faced by individuals in prostitution, but also a strong symbolic statement on the unacceptability of women's commercial sexual exploitation. Instead, we are witnessing a similar pattern of regional divergence in the application and interpretation of policy, and difficulties setting up effective partnership working among public services. In the absence of central government steering, interpretations about who can and should benefit from exit programme have often varied significantly between, on the one hand, Préfets and police authorities, and, on the other, women's rights delegates. Ultimately, only the former are officially empowered to decide, often opting to put policing and immigration control priorities ahead of support for those wishing to exit prostitution. The result has been that a small number of individuals have been able to benefit from state support to exit prostitution, while many have been turned away. At the same time, the ineffectual policing of the purchase of sexual services and a move away from street-based and towards internet-based prostitution have not led to an overall decrease in the phenomenon, let alone it's 'abolition'. In GEPP terms, the policy has had a low direct gender trans- formative impact.

Finally, there has been a conspicuous exclusion of non- or anti-abolitionist voices from discussions about the law both before and after its adoption. Many sex workers rights' and 
community health groups are particularly critical of the law's measure to criminalise clients, and have been since the option first emerged in the policy debate a decade ago. Their position rests on the belief that this measure makes prostitution less safe for those involved. During the legislative debate prior to the law's adoption, such criticism was comprehensively rejected by policymakers as unreasonable. Today, claims that these early fears have been borne out by a notable increase in the violence and precarity experienced by individuals in prostitution since the law's introduction continue to be dismissed by a dominant coalition of abolitionist actors who remain profoundly committed to the policy, considering it "a political project at the heart of the humanist values of our Republic" (Olivier in Caradec and Goldschmidt 2017; also see: cf. Rossignol and Billon 2018; Le Parisien 2019b; Coutelle et al. 2019). As a result, and despite consensus over its inadequate implementation, the law's symbolic value continues to be held above the reality and lived experience of individuals involved in prostitution.

The GEPP framework considers that, in order to be considered progressive, a pol- icy must empower women during the implementation process, and that to be considered empowering, the implementation process must be intersectional. Intersectionality in policy and implementation is that which "reflects the variety of demand of the groups and actors who make claims in the policy process" (Engeli and Mazur 2018: 117). While it has, at times, descriptively empowered a range of feminist actors both at a national and subnational level, the new French anti-prostitution policy nevertheless falls foul of this principle. The law was designed and is now being delivered exclusively by women's policy actors with avowed abolitionist beliefs. The corollary has been the automatic exclusion of voices that propose a different point of view on the validity and impact of the law. Currently, and in the absence of concrete evidence that the welfare of individuals in prostitution or societal gender norms have improved, the policy must therefore be classed as accommodating longstanding patterns of gender relations and historically uneven power constellation.

\section{Conclusion}

In April 2016, France became the fifth country to introduce a demand-side ban on prostitution as part of a reform intended to 'abolish' prostitution. The sweeping reform was the fruit of a long campaign to reframe prostitution as a form of violence against women. The new law comprised a social 'pillar' with measures to support individuals exit prostitution, and a criminal justice 'pillar' further punishing sexual exploitation and introducing a new penalty for the purchase of sexual services. The reform had a very strong normative component, signalling the state's belief that women's commercial sexual exploitation is unacceptable.

Advocates had high hopes for the new law. The country's post-war abolitionist regime had been notorious for its inconsistent and weak application, resulting in the further stigmatisation of individuals in prostitution. Yet, 4 years since its adoption, the new law is showing similar signs of being unevenly and incompletely applied. The 'exit programme' at the heart of its social 'pillar' has been difficult to introduce. Insufficient and inequitably distributed resources, and resistance from the police and immigration services, have led to very low numbers of programme beneficiaries. At the same time, regional police forces have weakly and inconsistently applied penalties against clients, undermining the law's normative and pedagogical intent. Overall, there is no evidence that the policy has had a significant direct impact on transforming gender relations. Despite early surveys hinting at growing 
public sup- port for the new policy, there has not been a substantial decrease in prostitution, especially when much of it may have moved online.

The implementation process has also seen the decreasing empowerment of feminist policy actors. The state's disinvestment from the issue signals a loss of salience as a priority on the policy agenda, and the once central role played by feminist actors in driving the policy debate has been stripped away. Meanwhile, département-level women's rights delegates substantively empowered to implement key elements of the law's social 'pillar' have struggled to deliver their operational responsibilities. Finally, the post-adoption phase has featured the continued exclusion of dissenting voices, predominantly from community health groups and sex workers' rights activists who criticise the criminalisation of clients. Claims that this measure has placed individuals in prostitution at greater risk by forcing them to operate in the shadows have been systematically rejected by a still-dominant abolitionist coalition for whom the law's symbolic value outweighs the poor implementation of its concrete measures to reduce prostitution. The result is a policy with whose implementation largely accommodates existing gender relations, with low direct impact on reducing overall prostitution and some evidence it has contributed to degrading the welfare of some of the more vulnerable individuals in prostitution. Nevertheless, the sustained dominance of abolitionist norms and values have crowded out alternative voices, in the continued defence of a policy regime often prized more for its symbolic value than its substantive one.

\section{References}

Abel, G., and L. Fitzgerald. 2010. Introduction. In Taking the Crime Out of Sex Work: New Zealand Sex Workers Fight for Decriminalization, ed. G. Abel and L. Fitzgerald, 1-23. Bristol: Policy Press.

Acceptess-T et al. 2019. Loi prostitution: Trois années de trop. Press Release, 15 April, https://www.medecinsdumonde.org/fr/actualites/prostitution/2019/04/15/loi-prostitutiontrois-annees-de-trop. Accessed 1 July 2019.

ActuToulouse. 2018. Prostitution à Toulouse: Une cinquantaine de clients ont été verbalisés Depuis 2016. 3 May, https://actu.fr/occitanie/toulouse_31555/prostitution-toulousecinquantaine-clients-verbalises-depuis-2016_16100245.html. Accessed 7 May 2018.

Adler, K.H. 1999. Reading National Identity: Gender and 'Prostitution' During the Occupation. Modern and Contemporary France 7 (1): 47-57.

Allwood, G. 2003. Sarkozy's Domestic Security Bill: War on prostitutes not on prostitution? Modern and Contemporary France 11 (2): 205-212.

Allwood, G. 2004. Prostitution Debates in France. Contemporary Politics 10 (2): 145-157.

Allwood, G. 2006. Prostitution in France. In International Approaches to Prostitution: Law and Policy in Europe and Asia, ed. G. Gangoli and N. Westmarland, 45-66. Bristol: The Policy Press. 
Amicale du Nid (2019) 3 ans après: Quel bilan pour la loi de lutte contre le système prostitutionnel? 18 April, http://amicaledunid.org/actualites/cp-3-ans-apres-quel-bilanpour-la-loi-de-lutte-contre-le- systeme-prostitutionnel/. Accessed 24 June 2019.

Barret, A.-L. (2013) Prostitution: qui sont les clients? Le Journal du Dimanche, 16 November, https://www.lejdd.fr/Societe/Prostitution-qui-sont-les-clients-639086. Accessed 5 May 2014.

Bize, B. (2019) Prostitution: 'Business as usual' sur les trottoirs de Poitiers malgrè la loi de 2016. Centre Presse, 17 February, https://www.centre-presse.fr/article-658408prostitution-business-as-usual-sur- les-trottoirs-de-poitiers-malgre-la-loi-de.html. Accessed 25 June 2019.

Brigaud, T. 2013. Pénaliser les clients de la prostitution: Un ticket pour la clandestinité. Mediapart, 5 November, https://blogs.mediapart.fr/edition/les-invites-demediapart/article/051113/penaliser-les-clients-de-la-prostitution-un-ticket-pour-laclandestinite. Accessed 26 March 2016.

Caradec, S., and S. Goldschmidt. 2017. Maud Olivier, rapporteure de la loi à l'Assemblée: "Cette loi demande des signaux politiques forts". Prostitution and Société 143: 4-5.

Charkaoui, M. 2018. Prostitution: Verbalisation des clients, les chiffres des amendes. Midi Libre, 27 April, https://www.midilibre.fr/2018/04/26/prostitution-verbalisation-des-clientsce-qu-il-faut-reten ir-apres-deux-ans-de-la-nouvelle-loi,1662588.php. Accessed 25 June 2019.

Colcombet, L. .2018. Loi prostitution: Un bilan très mitigé. Le Parisien, 14 April, http://www.leparisien.fr/faits-divers/loi-prostitution-un-bilan-tres-mitige-14-04-20187663554.php. Accessed 6 May 2018.

Corbin, A. 1996. Women for Hire: Prostitution and Sexuality in France After 1850 [translated from the French by Alan Sheridan]. Cambridge, MA: Harvard University Press.

Coutelle, C. et al. 2019. TRIBUNE. Prostitution: Une loi pour la dignité humaine. Nouvel Observateur, 14 January, https://www.nouvelobs.com/politique/20190114.OBS8441/tribune-prostitution-une-loipour-la-dignite-humaine.html. Accessed 21 January 2019.

Danet, J. 2006. Réflexions sur deux examples de politiques pénales locales autour de la prostitution. In Action Publique et Prostitution, ed. J. Danet and V. Guienne, 99-110. Rennes: Presses Universi- taires de Rennes.

Délégation aux Droits des Femmes du Sénat. 2018a. Table ronde sur le parcours de sortie de la prostitution. Senate report, 12 April, http://www.senat.fr/compte-renducommissions/20180409/femme s.html\#toc2. Accessed 2 June 2019. 
Délégation aux Droits des Femmes du Sénat. 2018b. Table ronde sur le parcours de sortie de la prostitution. Senate report, 29 November, http://www.senat.fr/compte-renducommissions/20181126/ddf. html. Accessed 2 June 2019.

La Dépêche. 2018. Olivier Arsac, adjoint au maire: «Notre rôle premier est le respect de la tranquillité». 8 March, https://www.ladepeche.fr/article/2018/03/08/2755566-olivierarsac-adjoint-maire-role- premier-est-respect-tranquillite.html. Accessed 25 April 2018.

Deschamps, C. 2007. La figure de l'étrangère dans la prostitution. Autrepart 42: 39-52. Dupont, S. 2018. Annexe no. 41: Solidarité et égalité des changes. In J. Giraud (ed.) Rapport Fait au Nom de la Commission des Finances, de l'Economie Générale et du Contrôle Budgétaire sur le Projet de Loi, Après Engagement de la Procedure Accélérée, de Règlement du Budget et d'Approbation des Comptes de l'Année 2017 (no. 980). Paris: Assemblée Nationale, n.p.

Engeli, I., and A. Mazur. 2018. Taking Implementation Seriously in Assessing Success: The Politics of Gender Equality Policy. European Journal of Politics and Gender 1 (1-2): 111-129.

Engeli, I., and F. Varone. 2011. Governing Morality Issues Through Procedural Policies. Swiss Political Science Review 17 (3): 239-258.

Freynet, A. 2019. Les visages de la prostitution en France. Le Point, 19 December, https://www.lepoint.fr/societe/les-visages-de-la-prostitution-en-france-19-12-20192354152_23.php. Accessed 5 February 2020.

Geoffroy, G. 2011. Rapport d'Information Déposé par la Commission des Lois Constitutionnelles, de la Législation et de l'Administration Générale de la République, en Conclusion des Travaux d'une Mission d'Information sur la Prostitution en France. Paris: Assemblée nationale.

Goldmann, C. 2018. Constats et préconisations-Système prostitutionnel: Bilan de la loi française d'avril 2016. GRASCO 24: 45-52.

Guérin, M. 2013. Le collectif “Abolition 2012" a organisé ce samedi une "journée d'abolition citoyenne du système prostituteur". Le mouvement abolitionniste renforce ses rangs.

Reportage. L'Express, 13 April, http://www.lexpress.fr/actualite/societe/prostitution-lesabolitionnistes-gagnent-du-terra in_1240083.html. Accessed 2 May 13.

Guienne, V. 2006. Politiques problématiques pour femmes publiques'. In Action Publique et Prostitution, ed. J. Danet and V. Guienne, 81-98. Rennes: Presses Universitaires de Rennes.

Guillemet, J.-P., and Pohu, H. 2019. Rapport d'Évaluation Locale de la Mise en Oeuvre de la Loi 2016- 444. Fondation Scelles and Bureau du Premier Ministre, http://www.fondationscelles.org/pdf/evaluation_locale/2019_Rapport_evaluation_locale_ mise_en_oeuvre_loi_2016_444_actualise\%CC\%81_juillet_2019.pdf, accessed 15 November 2019. 
Guiraud, E. 2009. Grande cause nationale 2010: La prostitution, une violence réaffirmée! Prostitution and Société, http://www.prostitutionetsociete.fr/societe/sexisme-egalitehommes-et-femmes/grand e-cause-nationale-2010-la. Accessed 30 May 2016.

IFOP. 2013. Les français et la prostitution (pour Causette). Survey, 4-6 February, http://www.ifop.com/media/poll/2180-1-study_file.pdf. Accessed on 5 August 2015.

Jeunes Radicaux de Gauche et al. 2013. Pour une approche réaliste de la prostitution. Libération, 24 September, http://www.liberation.fr/societe/2013/09/24/pour-uneapproche-realiste-de-la-prostituti on_934057. Accessed 28 October 2013.

Le Bail, H., C. Giametta, and N. Rassouw. 2018. Que Pensent les Travailleur.se.s du Sexe de la Loi Prostitution? Enquête sur l'Impacte de la Loi du 13 avril 2016 Contre le 'Aystème Prostitutionnel'. Paris: CNRS.

Lemettre, B. 2010. Pour un front de refus de la prostitution. L'Humanité, 6 February, http://www.human ite.fr/node/432462. Accessed 10 June 2011.

Le Nouvel Observateur. 2013a. Prostitution: la proposition de loi qui divise les partis. 29 November, http://tempsreel.nouvelobs.com/politique/20131128.OBS7515/prostitution-laproposition-de-loi- qui-divise-les-partis.html. Accessed 14 December 2014.

Le Nouvel Observateur. 2013b. Prostitution: la majorité des députés UMP finalement contre le projet de loi. 3 December, http://tempsreel.nouvelobs.com/societe/20131203.AFP4056/prostitution-la-major ite-desdeputes-ump-finalement-contre-le-projet-de-loi.html. Accessed 14 December 2014.

Le Parisien. 2018. Stage de sensibilisation: non, la prostitution n'est pas une partie de plaisir. 28 January, http://www.leparisien.fr/faits-divers/stage-de-sensibilisation-non-laprostitution-n-est-pas-une-parti e-de-plaisir-28-01-2018-7527864.php. Accessed 7 May 2018.

Le Parisien. 2019a. Prostitution: 71\% des Français hostiles à l'abrogation de la loi pénalisant les clients. 20 January, http://www.leparisien.fr/faits-divers/prostitution-71-des-francaishostiles-a-l-abrogation -de-la-loi-penalisant-les-clients-20-01-2019-7992849.php. Accessed 24 June 2019.

Le Parisien. 2019b. Prostitution: 'Monsieur le Premier Ministre, protégons notre modèle abolitionniste. 13 January, http://www.leparisien.fr/faits-divers/prostitution-monsieur-lepremier-ministre-protegeons-notre-modele-abolitionniste-13-01-2019-7987608.php. Accessed 21 January 2019.

L'Union. 2019. Prostitution: La loi de 2016 n'a pas encore produit d'effects. 24 October, https://www.lunion.fr/id103741/article/2019-10-24/prostitution-la-loi-de-2016-na-pasencore-produit-deffets. Accessed 13 November 2019. 
Maréchaux, G., and Burlet, L. 2018. Pénalisation des clients de prostituées: Lyon n'applique pas la loi mais les arrêtés municipaux. Rue89 Lyon, 9 April, https://www.rue89lyon.fr/2018/04/09/penalisation-des-clients-de-prostituees-lyonnapplique-pas-la-loi-mais-toujours-les-arretes-municipaux/. Accessed 20 April 2018.

Massonnet, C. 2016. 249 clients de prostituées mis à l'amende depuis cinq mois. Le Parisien, 28 Septem- ber, http://www.leparisien.fr/faits-divers/249-clients-de-prostituees-mis-a-Iamende-28-09-2016-6156167.php. Accessed 6 May 2018.

Mathieu, L. 2000. Prostitution et Sida: Sociologie d'une Épidémie et de sa Prévention. Paris: L'Harmattan.

Mathieu, L. 2001. Mobilisations de prostituées. Paris: Belin.

Mathieu, L. 2004. The Debate on Prostitution in France: A Conflict Between Abolitionism, Regulation and Prohibition. Journal of Contemporary European Studies 12 (2): 153-163.

Mathieu, L. 2011. Neighbors' Anxieties Against Prostitutes' Fears: Ambivalence and Repression in the Policing of Street Prostitution in France. Emotion, Space and Society 4: 113-120.

Mathieu, L. 2013a. La Fin du Tapin: Sociologie de la Croisade pour l'Abolition de la Prostitution. Lormont: Éditions François Bourin.

Mathieu, L. 2013b. Génèse et logiques des politiques de prostitution en France. Les Actes de la Recherche en Sciences Sociales 198 (3): 5-20.

Maugère, A. 2009. Les Politiques de la Prostitution: du Moyen Age au XXIe Siècle. Paris: Dalloz.

Mayer, S. 2011. Construction sociale de la "prostitution" et des "prostituées" par les riverains. Déviance et Société 35 (1): 35-58.

Mazur, A. 1995. Gender Bias and the State: Symbolic Reform at Work in Fifth Republic France. Pitts- burgh, PA: University of Pittsburgh Press.

Mazur, A. 2004. Prostitute Movements Face Elite Apathy and Gender-Biased Universalism in France. In The Politics of Prostitution: Women's Movements, Democratic States and the Globalisation of Sex Commerce, ed. J. Outshoorn, 123-143. Cambridge: Cambridge University Press.

Médecins du Monde et al. 2019. Un premier pas vers la censure de la loi prostitution de 2016. Press release, 12 November, https://www.medecinsdumonde.org/fr/actualites/prostitution/2018/11/12/un-premierpas-vers-la-censure-de-la-loi-prostitution-de-2016. Accessed 12 November 2018.

Milhat, A. 2017. La pénalisation des clients de prostituées se concretise. BFMTV, 4 April, 
https://www.bfmtv.com/police-justice/la-penalisation-des-clients-de-prostituees-seconcretise-1135536.html. Accessed 10 June 2017.

Ministère des Affaires Sociales et de la Santé. 2017. Circulaire no DGCS/B2/2017/18 du 31 janvier 2017 Relative à la Mise en Oeuvre du Parcours de Sortie de la Prostitution et $d^{\prime}$ Insertion Sociale et Pro-fessionnelle. Paris: Ministère des Affaires Sociales et de la Santé and Ministère des Familles, de l'Enfance et des Droits des Femmes.

Ministère des Familles, de l'Enfance et des Droits des Femmes. 2016. Décret no 2016-1467 du 28 octobre 2016 Relatif au Parcours de Sortie de la Prostitution et d'Insertion Sociale et Professionnelle et à l'Agrément des Associations Participant à son Élaboration et à sa Mise en Oeuvre. Paris: Ministère des Familles, de l'Enfance et des Droits des Femmes.

Ministère des Solidarités et de la Cohésion Sociale. 2010. Plan interministériel de lutte contre les violences faites aux femmes (2011/2013). Paris: Ministère des Solidarités et de la Cohésion Sociale.

Moran, A. 2019. Prostitution: un 'parcours de sortie' sans issue. Libération, 25 April, https://www.liberation.fr/france/2019/04/25/prostitution-un-parcours-de-sortie-sansissue_1723375. Accessed 24 June 2019.

Mouvement du Nid. 2010. Prostitution, une Seule Option: I'Abolition! Actes des Colloques Organisés par le Mouvement du Nid-France de may 2009 à février 2010. Paris: Mouvement du Nid.

Mouvement du Nid. 2017. Dossier: Les parcours de sortie. Prostitution and Société 143: 613.

Pacione, H. 2014. Prostitution: faut-il pénaliser les clients d'une amende de 1500€? La Dépêche, 13 July, http://www.ladepeche.fr/article/2014/07/13/1917898-prostitution-fautpenaliser-clients-amende-1500-e.html. Accessed 6 February 2015.

Rossignol, L., and Billon, A. 2018. Parce qu'il n'y a pas de prostitution heureuse, la loi doit continuer de la combattre. Huffington Post, 12 December, https://www.huffingtonpost.fr/laurence-rossignol/parce-quil-ny-a-pas-de-prostitutionheureuse-la-loi-doit-continuer-de-la-combattre_a_23615263/. Accessed 21 January 2019.

RTL. 2013. Le Grand Juy: Valérie Pécresse. Video, 1 December, http://www.rtl.fr/actu/politique/prostitution-valerie-pecresse-votera-contre-la-propositionde-loi-7767510300. Accessed 14 December 2014.

Seronet. 2019. Le Conseil constitutionnel valide la pénalisation des clients'. 4 February, https://www.seronet.info/article/le-conseil-constitutionnel-valide-la-penalisation-desclients-84000. Accessed 7 May 2019.

Skilbrei, M.-L., and C. Holmström. 2011. Is There a Nordic Prostitution Regime? Crime and Justice 40 (1): 479-517. 
Solé, J. 1993. L'Âge d'Or de la Prostitution de 1870 à Nos Jours. Paris: Librarie Plon.

St.Denny, E. 2016. Explaining the Emergence and Gradual Transformation of Policy Regimes: The Case of Contemporary French Prostitution Policy (1946-2016). Ph.D. thesis, Nottingham Trent University, Nottingham, UK.

St.Denny, E. 2017. The Gradual Transformation of a Weak But Enduring Regime: Contemporary French Prostitution Policy in Transition (1946-2016). Modern and Contemporary France 25 (3): 299-314.

Vantighem, V. 2017. Loi sur la prostitution: 937 clients ont étés verbalisés depuis l'entrée en vigeur de la nouvelle loi en avril 2016. 20 Minutes, 6 April, https://www.20minutes.fr/societe/2045295-20170406-loi-prostitution-937-clientsverbalises-depuis-entree-vigueur-nouvelle-loi-avril-2016. Accessed 10 October 2017.

Vernier, J. 2005. La Loi pour la sécurité intérieure: Punir les victimes du proxénétisme pour mieux les protéger? In La Prostitution à Paris, ed. M.-E. Handman and J. Mossuz-Lavau, 121152. Paris: Éditions de la Martinière.

Villeboeuf, P., and L.C. 2016. Loi antiprostitution: mauvaise passe à Fontainebleau. Le Parisien, 17 June, http://www.leparisien.fr/faits-divers/mauvaise-passe-a-fontainebleau-2706-2016-5916655.php. Accessed 10 June 2017.

Wagenaar, H. 2017. Why Prostitution Policy (Usually) Fails and What to do About It? Social Sciences 6 (2): 43-58.

Wagenaar, H., H. Amesberger, and S. Altink. 2017. Designing Prostitution Policy: Intention and Reality in Regulating the Sex Trade. Bristol: Policy Press.

Wagenaar, H., and S. Altink. 2012. Prostitution as Morality Politics or Why It Is Exceedingly Difficult To Design and Sustain Effective Prostitution Policy. Sexuality Research and Social Policy 9 (3): 279-292. 